\title{
From Victim to Martyr: A Feministic Study of Nayomi Munaweera's Island of a Thousand Mirrors
}

\section{P. Saranya}

\begin{abstract}
Literature flourished in Sri Lanka only in the post-independence era. The European rule of the island did not owe much to its literature. Post- independence era had a lot to contribute to literature and the ethnic tension also added to it. As a third world country, Sri Lanka had lot of memories to be shared. History, religion, politics, beauty of nature and violence in the country kept telling stories in the form of literature. As the ethnic tension widespread all over the country, people of both major ethnicity Sinhala and Tamil moved out of the country. Nayomi Munaweera is a one such writer who left the country due to war. At the age of three her family moved to Nigeria and from there they shifted to Unites States of America. Island of a Thousand Mirrors (ITM)was a debut novel of Munaweera which was published in 2012. Like two sides of a coin, the novel pictures the two views of one long brutal war through two female protagonists one belonging to the Tamils and the other to the Sinhalese. Her second novel What Lies Between Us was published in 2016. It reflected the inner struggle of the unnamed protagonist whose secrets made her tenuous from childhood to adulthood. As a female writer, Munaweera reflected the sufferings of the women during the time of war better than many male writers.
\end{abstract}

Keywords: Civil war, Women, Suffering, Martyr, Women, Tigers, Black Tigers.

\section{Introduction}

Wong and Santa Ana argues that "from the beginning, race and gender have been intertwined in Asian American history and literature”. (Wong \& Jeffrey, 1999)

In the view of literature, gender equality is spoken much by many women writers since early $19^{\text {th }}$ century. Women writers have contributed many works to literature. Literature portrays women in many ways as responding themselves to the social condition where they survive. In a third world country, especially in post -war situation, women are portrayed as a psychologically, mentally and physically strong who gains strength from within. The Sri Lankan literature portrays women in the same way as like the other literatures but what makes Sri Lankan literature unique, is its long torn civil war. The literature kept civil war as its central theme and the post-war works reflected only the consequences and sufferings of war. Novels became narratives of war. The life of the authors who experienced war became the subjects of their works.

The Colonial Ceylon during the British administration advocated girls' education in the country. It brought many social changes during the eighteenth and nineteenth century. This was promoted mainly among the elite class to establish knowledge and to produce 
Victorian wives, ladies and mothers and to suit the men of the elite's class. Shyam Selvadurai declares two contradictory statement of Sri Lankan women in his book The Hungry Ghosts, "Sri Lanka is the most sexist and violent place for women on earth and women were freer and better educated in Sri Lanka than in most of Asia". (Selvadura, 2013, p. 111)

After Independence, the role of women totally changed due to the Sinhalese domination. Women of elite class had all the privilege in all the fields whereas the women of middle class and lower suffer the same fate of patriarchy in hands of other men. The ethnic division in Sri Lanka in the post-colonial era marked the discrimination of minority ethnic groups like the Tamils, Muslims, Christians and Burghers. The women of these minority ethnic groups underwent double marginalization: one in the hands of country's political structure and the other in the hands of their own Patriarchal system. As of the year 2000 records, women constitute $0.9 \%$ of the military population in par with their male comrades. Women were believed to be unsuitable for warfare. Women were given only supportive roles, like medical, secretarial, transport, communication and clerical.

The beginning of twenty first saw Sri Lankan critics such as Thiru Kandaiah, Minoli Salgado, Yasmine Gooneratne, D.C.R.A. Goonetilleke, Chelva Kanganayakam, Ruvani Ranasinha and Maryse Jayasuriya have dissected and criticized the contribution of Sri Lanka expatriate writers to Anglophone literature in Sri Lanka. These critics focused more on the male writers such as Romesh Gunasekara, Michael Ondaatje, Shyam Selvadurai and Shehan Karunathilake and their works. Whereas the female expatriate writers of Sri Lanka like Nayomi Munaweera, V. V. Ganeshanathan, Mary Anne Mohanraj and Ru Freeman were given least importance in their critical works. These women writers also focused on Sri Lanka in their works from America but received less critical attention compared to their male counter parts.

Nayomi Munaweera who is a Sinhalese, was born in 1973. At the age of three her family moved to Nigeria to avoid the brewing Civil war. At the age of twelve, the family again moved to USA where they had bitter diasporic experience. The family suffered financially that the parents of Munaweera couldn't afford their children with good clothes. For this reason, Munaweera was denied by her friends in the school. Books were the best companion for her during her school days. Books saved her from marginalization.

Island of a Thousand Mirrors was a debut novel of Munaweera which was published in 2012. The book was nominated for Man Asian Literary Prize and won Commonwealth Regional Prize for Asia in 2013. It was also long listed for the International DUBLIN Literary Award and short listed for the DSC Prize for South Asian Literature.The story encircles the life of two girls Yasodhara and Saraswathi from two different ethnic groups, Sinhala and Tamil respectively. Their history was navigated in the backdrop of rivalries, heartbreaks, grievance of exile and belongingness, and sour demands of survival. Yasodhara and her siblings were brought up in a family which respects the value of life and people. Their peace was shattered by the riot and Yasodhara's family leaves the country to America. The second protagonist Saraswathi lives amidst the war field of Sri Lanka. Her future dream was fractured when she was arrested by the Sinhalese soldiers and dragged her into the heart of the conflict. She becomes a tigress to fight for the Tamil movement. In an unexpected way Munaweera brings both the protagonists in one scene to showcase the fate of the characters.

\section{Role of Women in War}

The prolonged ethnic conflict in Sri Lanka has burdened the role of women in Sri Lankan Society. The killing of men resulted in growing group of female-headed households in the families where women became the breadwinner of the family. Women play a 
multidimensional role in Sri Lankan ethnic war. Many women joined hands with many human rights organization and linked women's human rights to human rights problem in general. There were groups like 'Women for Peace', 'Mothers and daughters of Lanka' joined hands with the Liberation Tigers of Tamil Eelam (LTTE) and demanded for equal rights for women in the land which they are fighting for. In spite of many Women rights organization, women were not given equal rights in political decision-making of the country through the president was yet another woman. Neither at the highest level nor at the lowest level, women had active participation in the decision making during peace negotiations. The status of a woman depends upon the social, political and economic position of the men in the family and the women acts only as a subordinate to the men. Female combatants were found in the military but they act only as subordinates to the men in the Army. Women play an important role in wars and conflict around the world in the present scenario. Unlike other third world countries, Sri Lanka proclaims least despotic country in the case of women's right. Sri Lanka elected female prime ministers like Sirimavo Bandaranaike, Chandrika Bandaraike Kumaratunga and there were leading role played by women in the political parties.

The role of modern women in Sri Lanka is to act as the warehouse and signifiers of Ceylonese 'culture' and 'tradition' in the beginning of colonialism and in the post- colonial era they were considered as reproducers, nurturers, and stereotypes of 'tradition,' 'culture,' 'community,' and 'nation"'. Women are considered as a vehicle that transports and protects the culture and tradition of Sri Lanka both inside the country and outside the country. During the time of civil war, young girls of the northern part of the country were forced to join the Tigers and some willingly joined the movement. It was totally a different kind of treatment and role was played by women. They were treated as combatants, freedom fighters and separatists, fighting for a separate nation called Eelam.Women were recruited in the Tamil militancy of seven years after their male counterparts. According to Gunawardena 'LTTE'S female cadres also represent a type of feminist ideology, bolstering the LTTE contention that female emancipation is one of the key benefits it has achieved" (Gunawardena, 2006, p. 83). Their ideology was stronger than the men combatants. Female combatants constitute between 20-30 percent of the total LTTE, do so in order to liberate themselves from the Hindu culture. That is why they were named as 'Freedom Birds' or Sometimes referred by media as 'Black Tigresses' or 'Birds of Paradise'. Niromi de Soyza in her novel Tamil Tigress discusses the role of female students in the university and their incarnation,

Female university students were becoming part of the political movement, but they were not enlisted to be combatants. It didn't seem fair to me that, once again, women were denied equality when they were just as capable. The great Hindu Tamil poet Subramanya Bharathi had said so in the previous century and yet nothing had changed. The Hindu goddess Kali was the most valiant god of them all and yet women were expected to remain docile. (Soyza, 2011, p. 36)

It was the time when female students wanted to join the militant groups yet they were denied by the society. They were inspired by the poems of Subramanya Bharathi and the incarnation Kali. The young women wanted to involve themselves in the militant group projecting themselves as Kali.

\section{Black Tigers}

The first female Black Tiger was the women who involved in the assassination of Indian Prime Minister Rajiv Gandhi on May 21, 1991 in Sriperumpudur, India. It was the first successful attack by a female Black Tiger. They were trained from the early Stages of the 
adoption of suicide Terrorism. These female black Tigers had more Political and Organizational groundwork in the context of the Tamil Tigers. Gunawardena makes it to comprehend in a better way through the social and cultural backdrop as,

The self-sacrifice of the female bombers is almost an extension of the idea of motherhood in the Tamil culture, [as] in this strongly patriarchal society, Tamil mothers make great sacrifices for their sons on a daily basis; feeding them before themselves or the girl children, serving them

and so on. Acting as a human bomb is an understood and accepted offering for a woman who will never be a mother. (Gunawardane, 2006, p. 84)

As per the records, there was no married suicide bomber among the female Black Tigers and none were mothers. For women suicide Bombers, the act of destruction is both a moment of Victim hood and agency, though they are peace-loving by nature. Niromi de Soyza, in her novel Tamil Tigress elucidates the character of Akila, a female Black Tiger as,

Akila (Sakthiya Devi) died on 1 November 1995 (aged twenty-four) in the battle for Neerveli on the Jaffna Peninsula (where Theeban had also died ten years prior) against the Sri Lankan Forces. Surrounded by the Sri Lankan army, she ordered her unit to swallow cyanide and did the same herself, to avoid capture. At the time of her death, she was the deputy head of the women's intelligence wing and was posthumously awarded the title of lieutenant-colonel, the highest rank then achievable in the Tigers. She had been a wanted woman since 1991, for allegedly masterminding- together with Prabhakaran and then his deputy, Pottu Amman- the assassination of Rajiv Gandhi.

It was claimed that the suicide bomber who perpetrated the murder of Rajiv Gandhi had been a member of Akila's unit, as were other females involved in the attack; they included Akila's deputy, Lekha (not her real name or nom de guerre), who was arrested in India soon after the assassination and given the death sentence on being found guilty. In 1999 she was released on appeal into a refugee detention centre. (Soyza, 2011, pp. 300-301)

This autobiographical memoir sketches the life of a Tamil Tigress and their role among the Tigers. It is believed that women were holding equal cadre in par with the men among the Tigers. Gunawardena also argues that

There is a difference between men and women suicide attackers: women consider combat as a way to escape the predestined life that is expected of them. When women become human bombs, their intent is to make a statement not only in the name of a country, a religion, a leader, but also in the name of their gender. (Gunawardena, 2006, p. 85)

The above statement illustrates that the patriarchal structure dominates the societies in all disciplines and in all wars. The LTTE has changed the traditional face of the women from 'life-givers' to 'life-takers' by transforming them into human bombs.

Tunde Agara argues, "the feminine component of the human species who apart from serving as vehicle for nurturing human life is also a producer, a consumer and equally endowed agent for fostering a wholesome political, social and economic development in society" (Agara, 2015, p. 3). This perspective stresses that societal notion of women insists mothering, caring, maintaining peace and dependence upon men rather than provoking violence. The role of women changes in the present situation of becoming women soldiers, 
political leaders, managers or CEOs and even women becoming terrorists. In the present scenario feminism cannot be identified with the idea of militants, terrorists or suicide bombers but women involve in all the activities as men do.

The recent Sri Lankan literature is concerned with the suicide terrorism and the impact of society and culture play in accrediting martyrdom operations. If the society perceives women as weaker sex, the terrorist organisation breaks up the perspective of women and portrays them as suicide bombers and martyrs. Tunde Agara reviews the suicide Bombings as, "Suicide terrorism is the readiness to sacrifice one's life in the process of destroying or attempting to destroy a target to advance a political goal. The aim of the psychologically and physically war-trained terrorist is to die while destroying the enemy target". (Agara, 2015, p. 8)

\section{Feministic Study of Island of a Thousand Mirrors}

The fictional and non-fictional literature of Sri Lanka that was written in the aftermath era of civil war represents women in an unconventional way. They are no longer portrayed as symbol of fragility, innocence and weakness rather pictured as armed women in the discourse of terror and violence. The novel Island of a Thousand Mirrors portrays two women protagonist; betwixt the two, this research article will focus on Saraswathi who turns from a mediocre village girl to a Tiger who fights for the cause of the movement. The novel delineates from the traditional way of illustrating women as an object of subjugation but picture them as a strong militant. The concept of marriage is questioned and it subverts the picture of women in the role of sexuality and reproduction. Saraswathi's family feels proud when she ties the cyanide, She could feel "Wet pride shinning in their eyes" (Nayomi, 2013, p. 176). As she weds the LTTE by joining them,

She wears the rope of cyanide around her neck: "The Commandant steps onto the platform where we wait. He is the bridegroom, and we the various brides. I lower my head to receive his thali. Instead of the ancient golden symbols, it is a hard capsule of glass he places in the hollow of my throat. Seven seconds it whispers against my beating pulse. Seven seconds to freedom". (Nayomi, 2013, p. 176)

Saraswathi's thali elevates her status from Womanhood to a legitimate Tiger which brands her as a proud member of Liberation Tigers of Tamil Eelam. It gives them freedom that restricts the ordinary women. The Tiger proclaims the role of women as:

This is old-fashioned talk. Women are good for so much more than getting married and having babies. Our leader teaches that women are as brave as men. We too can fight as fearlessly, as ferociously. You must have greater goals for your daughter. What bigger aspiration could you have than for her to fight for her people? (Soyza, 2011, p. 142)

The novel not only subverts the concept of marriage but also it subverts the meaning of pregnancy. In the end of the novel, Saraswathi turns into a suicide bomber who becomes pregnant with destruction. The final preparation of Saraswathi as a bomber is compared with that of a bride and connects to pregnancy which will be expected from a married woman she explains:

Then with hands as gentle as Amma's, he pulls the contraption over my head, snuggles it against my belly, beneath my breasts. The Latex runs down my body like water...the secret mechanisms of it hidden in my now heavily pregnant stomach. 
When he leaves, I turn to my reflection and see what others will see, a young woman, eight months pregnant, green plastic bangles at her wrist, bright orange cloth hugging her belly. She is a ghost from a different time and place. Useless to me. (Soyza, 2011, p. 200 - 201)

In a traditional marriage, pregnancy gives a new life but in the case of Saraswathi, it provides only destruction. She immortalizes herself by becoming a martyr. Marriage, which is recognized as socially important in the milestone of women's life is reversible in the novel Saraswathi carries hidden violence in her stomach. She transformed the spoilt body into a tool which carries her vengeance towards the Sinhalese government. She is now no more a spoilt girl who the family feel ashamed of she is a new identity and a proud victim of her family. Violence has transformed her from a powerless victim to a powerful predator.

In her new transformation of a Tiger, Saraswathi is unburdened by gentle emotions. She commits murder with barbarous fierceness:

When the village is found, we want our message to be writ in red. We want to leave dead babies and bludgeoned women with streams of blood curling down the sides of their faces. To this end, I have learned to swing my machete through the flesh of babies. I have clutched the arm of a screaming toddler and swung off her head with a single blow as her mother stood with outstretched arms, voiceless in shock. I have disemboweled men and carved the breasts off their wives, sunk my knife into the hot brains of villagers... Now I am not just dancing a part. Now I am the Nataraja, the dancing face of death. Now I am the one with yellow eyes gleaming in the moonlit forest. The one who cannot be seen until she chooses to reveal herself. In this way I will never again be prey, small, trembling and weak. (Soyza, 2011, p. 177)

The illustration of violence in the hands of Saraswathi empowers the entire womanhood. The image of god Nataraja, a form of Hindu god Shiva symbols the image of destroyer Saraswathi is compared to Hindu goddess Durga and kali. She re-incarnates herself into those goddesses which interrupts the gender stereotypes of women as innocent, peacemaker and non-violent. She destroys her identity of a spoilt girl and transforms herself as a predator in the last journey of her life where she detonates the bomb buried inside her:

The bus lurches to a stop and I am in another place, a bullet-splattered cement room open to a perfect square of sky, ... Tiger Bitch. And I am tearing into shreds and something buried deep is erupting like a landmine, like rage buried in my flesh, something settled Tiger Bitch and burrowed under my heart like fetus raising its head. Tiger Bitch Tiger Bitch Tiger Bitch! (Soyza, 2011, p. 205)

When the Sinhalese calls her as 'Tiger Bitch', Saraswathi is reduced to the state of an animal but her rage is increased and moves further in achieving her goal.

Saraswathi compares herself with her friend Parvathi who has committed suicide after she was raped by the soldiers. She calls her as courageless victim and feels ashamed of her friend. In comparison with Parvathi, Saraswathi has not ended her life in trajectory rather she has changed herself into a martyr. The moment when she thinks of becoming a martyr, she feels proud at her action. Her mind flashes with the image what will happen to her as she imagines, "They will remember me. All of them. My portrait, miles high will hang everywhere extolling my bravery, the new cadres will come to stand in front of it, inhale the scent of my jasmine garland, be inspired by my fearlessness, my dedication. Amma and Appa will be proud. Luxshmi will be the sister of a martyr. (Soyza, 2011, p. 203) 
In a patriarchal society, Saraswathi and the other female militants have proved the empowerment of women. She stands as a connection between violence and empowerment. Even as a militant she dreams of the lagoon and her family but delineates herself from the thought, thinking that she is not born for being a school teacher. Her purpose of life was different. She wants to overcome the fear as she listens to her leader's words saying, "Fear of death is the cause of all human fears. One who wins over the fear of death wins himself. He is the one who wins freedom from his mental prison" (Soyza, 2011, p. 176).

The second protagonist Yasodhara and her sister Lanka also play a leading role in the novel. They are like Saraswathi who acts as a like-taker in the novel. They become the victims of war towards the end. Munaweera depicts one protagonist as an invisible force that spoils the life of other protagonist though they are not personally related. When Yasodhara's family was forced to immigrate to US, they found it difficult to move but the later life at US was full of prosperity. As like other immigrants they too found difficulty in settling in a new nation. Yasodhara tracks their growth as, "Yasodhara Rajasinghe: dusty, brown-winged bookworm. Lanka Rajasinghe: luminous, blue-green, glitter-winged butterfly” (Soyza, 2011, p. 117). They found a new root in the newly settled nation but the fate of the sisters and protagonists brought them together in a single roof. Munaweera created a plot where the two protagonists meet at their death point unknown to each other, one as a victim and the other as a murderer. The description of Lanka by Yasodhara brings sister-like feeling between them. It describes young girl's dream for her future family life:

A girl waiting in line with us catches my eye. Sinhala. My age, my height, masses of hair rising softly on the breeze, big eyes looking as if she wanted to ask questions. She doesn't belong here. Something in the way she holds her head, even though her clothes are local, the cut of the long skirt and the t-shirt like everyone else's, the bangles sliding on her thin wrist, green plastic like mine. But like me, she is an imposter from somewhere else.

I can see that she's in love. It's shining in her eyes. I can see that she wants the life she thinks I live. A young husband, and a baby on the way. She wants to lay her palms against my skin and feel my baby flutter. She wants to look into my eyes and feel sisterhood. She wants me to smile at her. But she cannot see what is buried in my heart, or the strange fruit that lies just beneath it. (Soyza, 2011, p. 204)

Through the long description of the meeting between Lanka and Saraswathi, Munaweera creates a bond between the two characters. But immediately their fate is decided by Saraswathi who blasts the bomb. "From the corner of my eye, I see the girl start towards me and I know her, but it is too late and my fingers are reaching down feeling for wires and now it is really too late..." (Soyza, 2011, p. 205). The final bomb blast made by Saraswathi blew up the life of two girls who shared the major part of the story. Saraswathi acted as an incarnation of kali, in showing her vengeance towards the Sinhalese people and the government.

The status of diaspora has given freedom and equal opportunity for female writers to express their ideas. In that way female writers have emerged in the post-civil war era portraying their country from diasporic situation. The have double consciousness towards the nation. One is of being the native of Sri Lanka and the other is of an immigrant. Munaweera has depicted war from the side of both ethnic groups through her two female protagonists.

Munaweera did not stop the life of Saraswathi with her rape incident but has 


\section{Mirrors}

portrayed a life for her even after such cruel incident. If Saraswathi had entered into familial life, she would be bounded by the patriarch ideology that will again prison her life. But the representation of Saraswathi as a martyr mitigate he identity as a rape victim. Munaweera has taken the weapon of violence in shaping her one of the female protagonist who acts as a role model in reshaping the life of other women.

War has made women strong only in this novel. In Sri Lanka, many women after war have lost home, children, husband and even their economic status, which made their condition more pitiable than before. In the Tamil areas in Sri Lanka which was affected by war, many houses were evacuated and some refugees went back to their places and have not regained house or land. Many female militants were rescued from the movement and were given counseling to move forward with life. Literature acts as a catalyst in bringing peace and a bright future for the victims of war.

\section{References}

Agara, T. (2015). Gendering terrorism: Women, gender, terrorism and suicide bombers. International Journal of Humanities and Social Science, 5, 6-1, 115- 125. www.ijhssnet.com/journals/Vol_5_No_6_1_June_2015/13.pdf.

De Soysza, Niromi. (2011). Tamil Tigress. Mehta Publishing House.

Gunawardena, Arjuna. (2006). Female Black Tigers: A Different Breed of Cat? In Yoram Schweitzer (Ed.) 81-90. www.jstor.org/stable/resrep08943.9

Munaweera, Nayomi. (2013). Island of a Thousand Mirrors. Hachette Book Publishing India Pvt. Ltd.

Selvadurai, Shyam. (2013). The Hungry Ghosts. Penguin Books India.

Wong, Sau-ling C. and Jeffrey J. Santa Ana. (1999). Gender and Sexuality in Asian American Literature. 25(1), 171-226. https://www.jstor.org/stable/3175619.

\section{Bio-note}

Dr. P. Saranya has completed her $\mathrm{PhD}$ from Government Arts and Science College, Coimbatore, Tamilnadu. She has qualified NTA (UGC) NET Examination in July, 2019. Her areas of interest are diasporic Literature, Sri Lankan Literature, British Literature and Canadian Literature.

Email Id: saran.p1771@gmail.com 